\title{
Gender differences in farm entrepreneurship: comparing farming performance of women and men in Italy
}

\author{
Felice Adinolfi ${ }^{\star}$, Fabian Capitanio*, Marcello De Rosa*, Yari Vecchio*
}

\author{
DOI: $10.30682 / \mathrm{nm} 2001 \mathrm{e}$ \\ JEL codes: C1, J16, Q12
}

\begin{abstract}
Gender differences in rural enterprise are a relevant field of analysis which calls for a deeper investigation concerning key variables affecting farm's performance and on the basis of gender. This paper tries to explore eventual gender gaps in the farms of Italy. Two variables are investigated: "Who" variable discriminate farm's manager on the basis of gender under a constituent perspective of female entrepreneurship. "Where" context is articulated in business, social and spatial context, with the aim of excavating the multiple dimensions of farm entrepreneurship. In order to bring out the differences between male and female condominium farms in Italy, an econometric model was applied, with the aim of identifying context-related differences. The results confirm gender gaps related to farm performance, networking, diversification strategies and access to rural policies, by enlightening diverse paths of development in rural enterprises on the basis of explanatory variables. Therefore, adopted methodology reveals its utility in explaining gender gaps and addressing targeted policy implication at the beginning of a new programming era for the Common Agricultural Policy of the EU.
\end{abstract}

Key words: Gender Gaps, Context, Rural Enterprise.

\section{Introduction}

The relevance of women in agriculture has been deeply recognized in recent literature, even though in terms of family farming labour and not in terms of contribution to decision making (Davidova and Thomson, 2014). This paper deals with gender differences in agricultural sector, according to a constituent perspective of women's role in agriculture (Whatmore, 1994).

The aim of the paper is to provide evidence of eventual differences between men and women's performance. This theme is not a novelty. Since the seminal works of 70's and 80's, gender differences in farming activities have been in- vestigated under different perspectives and theoretical approaches, pointing out women's role in agricultural activity and in the rural context (Sachs, 1983; Errington and Gasson, 1993; Little, 2006). What has marked recent evolution in theoretical analyses is the search for new direction of research (Hughes et al., 2012) grounded on a clear transition from structuralist towards constructivist approaches, where feminist project takes place within new and differentiated rules of identity and entitlement (Seuneke and Bock, 2015; Prügl, 2009). Set against this background, this paper tries to contribute to literature by emphasizing key differences in farm manage-

\footnotetext{
* Università degli Studi di Bologna, Scuola di Agraria e Medicina Veterinaria, Bologna, Italy.

Corresponding author: yari.vecchio@unibo.it
} 
ment and strategic decision making at farm level between female and male farms. Therefore, unit of analysis is the farm managed by women as differentiated by farms managed by men. Consequent research questions are:

RQ1: are there significant differences in portfolio strategy and economic performance in male/female farms?

RQ2: to which extent, processes of gender mainstreaming are effective in the Italian agriculture?

In order to answer these questions, we approach the analysis from a 'context lens' (Welter, 2011), which has not been given the necessary attention in recent studies on female farm entrepreneurship. With this respect, we assert that this paper fills a gap in literature, because there are no studies facing in a comprehensive perspective questions relating to business, social, territorial and political context as we intend to verify with the empirical analysis.

The paper is structured as follows: paragraph 2 puts forward a brief theoretical background. The aim is not to provide a deep literature review, but just to focus on the key aspects the following empirical analysis will be centered around. Paragraph 3 describes methodology and data collection, while paragraph 4 is devoted to the main results. Final paragraph will concentrate on discussion and conclusions.

\section{Theoretical background: contextualizing gender issues on farm entrepreneurship}

Scientific analyses concerning gender differences in rural areas have been characterized as context-sensitive researches (Welter, Gartner, and Wright, 2016). As Welter (2011) points out, correctly questioning entrepreneurship calls for contextualizing entrepreneurship, in that "contextualization is about recognizing differences" (Welter, Gartner, and Wright, 2016). This is particularly true in cases of female entrepreneurship (Welter, Brush, de Bruin, 2014).

To fully understand the meaning and the relevance of the term, we make reference to Griffin's analysis (2007): he distinguishes between omnibus context, in that context is considered as a "lens", and discrete context, where it is con- sidered as a variable. However, the omnibus context has to be privileged in order to open the black box of entrepreneurial mind (Elfving, Brännback, Carsrud, 2017). Consequently, by following Welter, context has to be taken into account from following perspectives: Who, Where, When. The first two (who + where) will be examined in this paper, while when variable will be deepened in further studies.

The first variable is "Who", that is the identity of entrepreneur. This may seem a trivial question, but it is not, because it involves different aspects. Moore (1999) points out that women and men entrepreneurs need to be investigated within various entrepreneurial groups (Popescu, 2012). A first element of distinction is, of course, gender. It is commonly accepted in literature that gender differences need to be addressed in analyzing entrepreneurial performance at farm level and that a question of gender mainstreaming in rural areas need to be faced. In this paper, we intend to follow a constituent perspective on female farming (Whatmore, 1994) where female manager take on strategies for developing farm business under the hypothesis of a "visible participation" (Little, Panelli, 2003) and of "willing reproduction" (Heather et al., 2005), where decision-making process is under women's responsibility. This may represent a limit of our analysis, in account of the male's predominance in decision-making processes in family farm business (Contzen and Forney, 2017).

The second context lens is "Where", which "refers to the manifold locations in which entrepreneurship happens, all of which have an impact on "who"" (Welter, 2011, p.167). According to the original institutional theories, different productive contexts originate different socialization forms, bringing about a sort of pluralism in the modern society (Durkheim, 1895; Nau and Steiner, 2002; Richter, 1996). Set against this background, following Welter's suggestion, "where" context needs to be clarified by taking into account business, social and spatial context.

Business context is related to the type of market. More precisely, as far as farm female entrepreneurship is concerned, type of activity privileged by women in agriculture is at stake, with the purpose of comparing the hypothesis (H1) 
that women are either or not less business successful than man. As a matter of fact, gender gap in economic performances has been widely recognized (Coleman, 2002; Bird and Sapp, 2004; Brush and Chaganti, 1999; Watson and Newby, 2005; Marlow and McAdam, 2013), highlighting a number of factors explaining the apparent underperformance of women's business (Fairlie and Robb, 2009). At aggregate level, women often result running small business in less profitable sectors (Brush and Chaganti, 1999; Fasci and Valdez, 1998; Rosa et al., 1994) and many empirical studies have focussed on systematic gender differences in business performance. The causes have been widely debated following two main theoretical perspectives (Carter and Weeks, 2002; Mirchandani, 1999). The liberal feminist theory explains the women relative disadvantage as the result of their difficulty, grounded on discriminatory factors (Kalleberg and Leicht, 1991), to access resources (human and financial capital) for business development (Fischer, Reuber, and Dyke, 1993; Lowe and Lowe Bentson, 1984). In contrast, the socialist feminist theory identifies the gender-related differences in socialization process as the main source in explaining why female-owned business under-perform the maleowned (Fischer, Reuber, and Dyke, 1993; Calás and Smircich, 2006; Robb and Watson, 2010). It is the result of different behaviour of women towards risk and growth, merged with different goals pursued (Jones and Tullous, 2002). Both perspectives have offered interesting insights and especially in recent years, many empirical studies have taken into account variables from both sides as potential sources of female disadvantage in running business (Carter, Williams and Reynold, 1997; Fairlie and Robb, 2009; Robb and Watson, 2010; Swinney et al., 2006).

A second element concerning business context is related to types of activity privileged by male/ female farms and more precisely to portfolio strategies adopted by farms (Alsos et al., 2014), sometimes nurtured by processes of co-preneurship (Bensemann, Hall, 2010). ${ }^{1}$ By taking into account farm's specific strategies to ensure success (McElwee, Bosworth, 2010), we would like to discuss the propensity towards farm diversification in female farms with respect to male farms. Diversification is a typical example of boundary shift strategy to escape price-costs squeeze (Banks, Long, van der Ploeg, 2002; van der Ploeg, Marsden, 2008; Vik, McElwee, 2011). As underlined by Trauger (2004), if on the one side, productivist paradigm has progressively marginalized women, on the other side, sustainable agricultural models revitalize women in the new scenario of modern rurality. As a matter of fact, diversification represents an opportunity to re-ground farming activities better combining business and family duties. This type of entrepreneurial strategy can be carried out either in or off farm. Diversification in the farm is oriented towards either agricultural (for example, direct selling) or not agricultural activities, for example agritourism (Vik, McElwee, 2011). Consequently, a further hypothesis we intend to test in this paper $(\mathrm{H} 2)$ is the eventually higher women's propensity towards diversification of farm activities. This hypothesis arises from both the gendered perception of most farming "not traditional" activities (McGehee et al., 2007; Shortall, 2006) and the ability of women in activating underexploited local resources (Anthopoulou, 2010). The first argument is linked to the nature of the main options involving in farm diversification strategies (food processing, accommodation, direct selling) that have been traditionally covered in rural areas by women activities (Bock, 2004). The second is the result of women's engagement in finding opportunities to overcome the hegemonic construct based on both masculine working practices (Oughton et al., 2003; Shortall, 2002; Whatmore, 2016) and clear distinction of professional tasks between man and women (Brandth, 2002; Little, 1987). In addition, this hypothesis may be the result of concomitant factors resulting in difference between female and male-owned business in resource endowment, as well in gender attitudes

${ }^{1}$ As underlined by Bensemann, Hall (2010), "Couples in business together (co-preneurs) are one form of family business". 
(Loscocco et al., 1991; Robb and Watson, 2010). Actually, the overlap between productive and reproductive sphere (Delphy, 1983) brings about "commodification of motherhood" (Anthopoulou, 2010) that makes women more strained by domestic responsibilities than man (Fairlie and Robb, 2009), encouraging women to seek more flexible pathways in terms of work organization (Boden,1999; Bird and Sapp, 2004; Scott, 1986).

As far as social context is concerned, it traditionally refers to the networks the entrepreneurs are involved. For an entrepreneur to be successful relational assets represent key factors to be investigated: interorganizational and social networking activity needs to be taken into account (De Hoyos-Ruperto et al., 2013; Johannisson and Nilsson, 1989). In some cases, these relationships are locally embedded and engagement in local networks provides access to local resources (McKeever, Anderson, and Jack, 2014). In other cases, they are built on non-local networks. There is not a unique view about which type of relations are to be preferred, being both placial embeddedness and non-local networks identified as "the best of two worlds" (Korsgaard, Ferguson and Gaddefors, 2015). Therefore, the hypothesis to be investigated (H3) is that female-owned business networking is less developed. One of the main dimensions influenced by differences in both social values and differences in resource availability is the quality of business networking. It involves the access to services (credit, information, training) as well the role played by both social structure and family responsibilities in the developed of female-owned business endowment (Hanson and Blake, 2009; Kalleberg and Leicht, 1991). Past researches suggest that female business is characterized by fewer network than man (Cromie and Birley, 1992; Orhan, 2001). In particular, the participation of women in formal network appears weaker, while they are more likely to be included in informal cluster (Moore, 1990). It results in a less integration of female-owned entrepreneurs into business network. This leads to a more limited use by women of both resources (credit, information, and training) and partnership opportunities (Bird and Sapp, 2004; Stratigaki, 2005). In rural areas role played by a more hegemonic masculine construct (Brandth, 2002; Rieux \&
Dahache, 2007; Shortall, 2002) makes for a very sensitive subject for scholars and policy-maker (Bock, 2004; Little and Jones, 2000; Stratigaki, 2005; Whatmore, 2016). Many works on this field have confirmed the hypothesis that female farmers are less involved in building formal synergies and networks (Blumberg, 1988; Loscocco and Robinson, 1991; Oughton et al., 2003; Tigges and Green, 1994; Shortall, 2002). Moreover, recent literature points out how mechanism of power may affect the feminist engagement with the State (Prügl, 2009).

Consequently, our paper tries to evaluate the propensity to adhere networks in rural contexts and to create socialization spaces.

Networking activities happen on a territorial scale, through joining organizational and territorial proximities (Torre, Traversac, 2011). Territorial localization is relevant in this context, in order to define entrepreneurial processes: consequently, spatial contexts are also to be investigated. Farms located in rural or urban areas develop different strategies and get different opportunities, which may raise also the "social distance" between male and female farms. Therefore, considering farm's territorial localization is a key point in the analysis.

The previous variables considered bring about a deeper articulation in policy approach, which should cast gender issues in the policy agenda. This aspect is taking on a growing importance in the light of the mainstreaming process that since 1998 has been adopted at political level with the aim of incorporating a gender equality perspective in all policies (Council of Europe, 1998). As largely recognized, although EU programmes include specific framework aimed at promoting gender mainstreaming in rural areas (Hafner-Burton and Pollack, 2009), the followed approach remain still anchored to traditional "masculine" criteria (Bock, 2004; Anthopoulou, 2010). It is the case of the eligibility criteria used for defining potential beneficiaries of some common agricultural policy (CAP) measures, providing minimum thresholds of labour input and farmland. Empirical evidences support the idea that female-owned rural businesses are less likely to access to CAP support, including rural development (RD) measures, than man (Bock, 2004; Shortall, 2002). 
Therefore, a final hypothesis to be empirically verified (H4) concern women's aptitude to gain access to RDP with respect to male farms. Access to RDP is a key element to overcome barriers to credit for farms. As recently underlined in literature (Leitch, Henry, 2018, p. 105), "a complex range of variables undoubtedly affects female entrepreneurs", for example institutional, cultural and historical factors. Thus, different profiles of financial networks may typify men and women in account of different social capital addressing entrepreneur's behaviours (Alakaleek, Cooper 2018; Naegels et al., 2018).

\section{Empirical analysis}

In order to test the hypotheses above introduced (H1-H4), econometric models have been tested. More precisely, as far as the first hypothesis is concerned (H1), related to business context, the model tries to verify differences in farm's performance between male and female farmers.

Consequently, the empirical approach adopted is, firstly, aiming to explain the gender farmers' performance by socio-economics characteristics of farms, H1 (Polman and Slangen, 2008). For these purposes we carried out a logistic model with fixed effect, so that:

$$
\operatorname{Pr}\left(y_{i}=1\right)=\mu\left(\beta^{\prime} x_{i}\right)
$$

where $\beta$ represents the fixed parameters vector. The assumptions underlying the model are that the binary variables (male versus woman) are determinations of independent random variables. It is assumed that the reverse link function $\mu=\mu(s)$ would be continuous, differentiable up to the second order and strictly increasing.

The function (1) cold be rewrite as, $E\left(y_{i} \mid x_{i}\right)=\mu\left(\beta^{\prime} x_{i}\right)$ and can be generalized by including the "random effects", so as to estimate the components of the regression parameters specific for each group, if we consider the employees observations constituting the groups themselves. In such eventuality, the model is

$$
\operatorname{Pr}\left(y_{i j}=1 \mid b_{i}\right)=\mu\left(\beta^{\prime} x_{i j}+b^{\prime} z_{i j}\right)
$$

where $i$ and $j$ respectively are the cultivar revenue and the farmers size, $z_{i j}$ is the vector of the fixed effects and $b_{i}$ is the vector of the random effects.

Furthermore, the same econometrics approach (Greene, 2000) has been used for testing H2, H3 and H4. This choice is in order to both take into account the nature of the decisions investigated and appropriately manage variables that can be complementary.

Respectively, to test $\mathrm{H} 2$ aiming to verify if there are gender-based differences in the structure of relationships with external sources and networks. As underlined in theoretical background, relational assets play a relevant role in boosting farm's performance and may be synthesised with farmers' propensity to adhere associative organisms. The third hypothesis (H3) allows examining the aptitude of male and female-owned farmers towards diversification as tool for shifting traditional farm's boundaries (Banks, Long, van der Ploeg, 2002). The latest model tests $\mathrm{H} 4$, analysing whether there are gender differences to catch RDP fund, as tool for supporting farm's strategies of development. As explained in theoretical part, capability of gaining access to rural policies has to be considered as the exit of an entrepreneurial orientation, but it is also linked to a set of socio-institutional factors that have to be taken into account.

\subsection{Data}

Our empirical analysis is based on the information from a balanced panel of the Farm Accountancy Data Network (FADN) since 2009 until 2015. This dataset contains detailed information on 6,234 Italian farmers. The Council for research in agriculture and agricultural economics (CREA) is responsible for collecting and organizing the FADN on a yearly basis. ${ }^{2}$ The data are representative for the population of farmers

2 The sample is stratified on three key variables, i.e. location (21 NUTS2 regions), economic size (6 classes) and farm types (19 types) (INEA, 2010). We use the information related to farm location to attach site-specific variables to each observation. 
in Italy. Data are validated by the National Institute of Statistics (ISTAT).

In this study, to test H1 we select the types of explanatory variable that we consider as a proxy of business successful, e.g. return on investment (ROI), considering as independent variables farmers localization, ${ }^{3}$ farmer size (small, medium and large), education, member of professional organization $(P O)$ and social network (assoc) and structure (fixasset). The aim of the analysis, for each hypothesis, is to capture the differences between men and women with respect to the value of the dependent variable. To investigate on $\mathrm{H} 2$, gender differences attitudes on diversification of farmer activities, we consider as dependent variable the crop specialization degree; ${ }^{4}$ we used as independent variables the altitude of the farms localization, ${ }^{5}$ member of professional organization (PO) and social network (assoc), organic production, farmhouse.

Concerning the $\mathrm{H} 3$, we consider as dependent variable the participation of farmers to market mechanism, e.g. value chain, considering as independent variables relevant for our purposes higher and/or specialized degree of education, localization, the access of farmers to financial services, the use of services aimed at support human capital.

To test $\mathrm{H} 4$ (differences in gender aptitude to gain access to RDP measures as dependent variable), we consider farmer localization, ${ }^{6}$ farm size, education, crop diversification, organic production, structure and the access of farmer to financial services (Wynn et al., 2001; Damianos and Giannakopoulos, 2002; Vanslembrouck et al., 2002; Polman and Slangen, 2008; Defrancesco et al., 2008; Peerlings and Polman, 2009). Secondly, previous findings have confirmed that the type of agri-environmental payments used by farmers can vary because it is dependent on the type of farming system (Unay-Gailhard, Bojnec, 2015; 2016; 2019; Wynn et al., 2001; Vanslembrouck et al., 2002; Polman and Slangen, 2008).
For example, participation in an agri-environmental scheme of an intensive and specialized dairy farm is different from participation in the same type of contract of a specialized arable farm (Polman and Slangen, 2008). Consequently, we will take into account the variables related to labour use (fam_labor), off-farm income (offfarm), land tenure (uaa_rent) and farm management (dev_plan, acc_serv).

Polman and Slangen (2008) also highlighted the role of social capital in conditioning this type of contractual choice. Therefore, we included indicators related to participation in professional and social networks (coop, assoc) too.

\section{Results}

Estimation results and measures to assess the goodness of fit of our model are reported in table 2. Maximum likelihood estimates were obtained using STATA 10. First of all, we discuss the robustness test and then the impact and significance of each explanatory variable. In order to control multicollinearity, we checked pairwise correlation coefficients between all variables used in the model. None of the pairwise correlation coefficients exceeded 0.5 . We also calculated the variance inflation factors (VIF) using OLS (thus basically assuming linear probability model specifications). The highest VIF was 6.23 (average of 3.78), below the critical value normally set at 10 (Hill and Adkins, 2001). We also tested for multiplicative heteroskedasticity by using the Breusch-Pagan / Cook-Weisberg test, and the general Wald test statistic.

Concerning H1, we found that for the overall sample business successful is positively affected by education, fix asset, size and social network; weakly the impact of the variable $P O$. It is interesting to emphasize that if we consider separately women and man, for the former the main impact on dependent variable could be identified in education, $P O$ and assoc; for the latter sub-

\footnotetext{
${ }^{3}$ Area $1=$ North; Area $2=$ Middle; Area $3=$ South.

${ }^{4}$ We consider the index 1 if a share up to $50 \%$ of the overall crop revenue is related at single crop; 0 otherwise.

5 The hypothesis is that mountain and hill farms have more difficulty accessing forms of income other than agriculture.

${ }^{6}$ It is known that the budget for second pillar measures is higher in some areas of the country.
} 
Table 1 - Description of variables.

\begin{tabular}{|c|c|c|c|c|}
\hline \multicolumn{2}{|c|}{ Variables } & Explanation & Mean & $\begin{array}{l}\text { Standard } \\
\text { deviation }\end{array}$ \\
\hline \multicolumn{5}{|c|}{ Dependent variables } \\
\hline \multicolumn{2}{|c|}{ Participating in rural development policy } & 1 if farmer participates & 0.053 & _ \\
\hline \multicolumn{2}{|c|}{ Participating in agri-environmental } & 1 if farmer participates & 0.081 & _ \\
\hline \multicolumn{5}{|c|}{ Internal factors (farm/farmer) } \\
\hline \multicolumn{5}{|l|}{ Farm characteristics } \\
\hline \multirow[t]{2}{*}{ Farm size } & $\operatorname{small}^{(a)}$ & 0 if farm $<16 \mathrm{ESU}$ & 0.31 & 0.67 \\
\hline & Medium-Large & 1 if farm $>16 \mathrm{ESU}$ & 0.43 & 0.89 \\
\hline Farm structure & fixasset $^{(a)}$ & Total fixed assets & 6,460 & 11,428 \\
\hline \multirow{4}{*}{ Farm specialization } & $\operatorname{arable}^{(\mathrm{a})}$ & $\begin{array}{l}1 \text { if specializing in arable crop } \\
\text { production }\end{array}$ & 0.39 & 0.12 \\
\hline & horticult (a) $^{(2)}$ & 1 if specializing in horticulture & 0.65 & 0.11 \\
\hline & perm_crop ${ }^{(\mathrm{a})}$ & 1 if specializing in permanent crops & 0.08 & 0.56 \\
\hline & livestock $^{(\mathrm{a})}$ & 1 if specializing in livestock & 0.02 & 0.95 \\
\hline \multirow{3}{*}{ Labour use } & $l u \_u a a^{(\mathrm{a})}$ & \begin{tabular}{|l} 
Labour intensity measured in Annual \\
Working Units (AWUs) per hectare of \\
Utilized Agricultural Area (UAA)
\end{tabular} & 6.32 & 97.64 \\
\hline & fam_labor $r^{(\mathrm{a})}$ & $\%$ AWU provided by family members & 51.43 & 34.11 \\
\hline & offfarm & 1 if family off-farm labour is present & 15.43 & 79.48 \\
\hline Land tenancy & uaa_rent ${ }^{(\mathrm{a})}$ & $\%$ UAA rented & 28.76 & 36.78 \\
\hline \multirow[t]{2}{*}{ Farm management } & dev_plan ${ }^{(a)}$ & $\begin{array}{l}1 \text { if farm follows a business plan for } \\
\text { development }\end{array}$ & 0.43 & 0.92 \\
\hline & $a c c \_s e r v^{(a)}$ & 1 if farm uses an advisory service & 0.07 & 0.41 \\
\hline \multicolumn{5}{|l|}{ Farmer characteristics } \\
\hline Type of land manager & manager ${ }^{(a)}$ & 1 if manager also provides farm labour & 0.97 & 0.38 \\
\hline \multicolumn{5}{|c|}{ External factors } \\
\hline \multicolumn{5}{|l|}{ Social capital } \\
\hline \multirow[t]{2}{*}{ Networks } & $\operatorname{coop}^{(\mathrm{a})}$ & $\begin{array}{l}1 \text { if member of agriculture-related } \\
\text { cooperative }\end{array}$ & 0.29 & 0.61 \\
\hline & $\operatorname{assoc}^{(\mathrm{a})}$ & 1 if member of an association & 0.24 & 0.72 \\
\hline \multicolumn{5}{|l|}{ Farm location } \\
\hline Population density & pop_den ${ }^{(\mathrm{c})}$ & Population density per $\mathrm{km}^{2}$ & 98.68 & 698.24 \\
\hline Mountain & mount $t^{(\mathrm{b})}$ & 1 if located in a mountainous area & 0.11 & 0.96 \\
\hline
\end{tabular}

Source: (a) INEA, 2012; (b) MIPAAF, 2011; (c) ISTAT, 2010.

sample, education impact is quite weaker meanwhile size, fix asset and $P O$ are the variables that guarantee the greatest impact on ROI. The sta- tistical significance of the independent variables denotes higher propensity of women than men to have successful economic results; worthy of 
note is the result of the incidence of the $P O$ variable for the women sub-sample, which for the entire sample is instead a variable that has lower significance on the result of the dependent variable. Without statistical significance the variables farmer size and farmer localization.

Results for $\mathrm{H} 2$ emphasize that altitude, farmhouse and organic are the variables that most affect the diversification for the joint sample; it is interesting to remark how the $P O$ and assoc variable becomes statistically significant for the subsample of women. This result would appear controversial; a possible explanation can be found in the greater propensity of women who are associated with a management of the crop portfolio that diversifies risk more efficiently. Otherwise, as women are average representatives of smaller companies, it is a strategy induced by a most difficult relationship with the credit.

Results for H3 underline that the ability to network would be strictly linked to education, firstly, financial services and services for human capital; less statistical significance for localization. Interesting the result for women subsample that underline how financial services is without statistical significance; this result may be associated probably with the lower degree of access to credit for women. In overall, the statistical significance of the independent variables denotes a lower propensity of women than men to have a profitable network.

Analyzing results for $\mathrm{H} 4$, the first aspect to underline is that both being a small farm (small) and farms with higher values of assets (fixasset) increases the probability of participation in $\mathrm{Ru}-$ ral Development Policy.

This eventuality can be understood in light of the fact that farms with more assets (land, stables, buildings, machinery, etc.) have higher benefits in investing in renewing such assets than farms with lower asset endowments. Concerning the farm diversification, the results indicate that the type of measures foreseen in the II Pillar are not currently targeting the interests of specialized farmers e.g. permanent-crop farms. The results show that family farms (fam_labor) have a high probability of participating in RDP as well as high education (education). Family labour can be allocated to activities related to
RDP contracts, experiencing lower opportunity costs than professional farms; without statistical significance the off-farm work (offfarm) and organic production (organic).

The adoption and the use of advisory services (acc_serv) increase the probability of participating in RDP, especially for the man sub-sample. Concerning the explanatory variables concerning social capital issues, farmers who are members of a cooperative or professional association (assoc) are less likely to participate in RDP, perhaps due to their more focus on the market measures (first Pillar of the Common Agricultural Policy).

Finally, with respect to farm location, our findings suggest that being located in urban areas (Area 1) increases the probability; being located in both Area 2 and 3 loses significance (perhaps this result could be related at the lower expenditure efficiency in these area in Italy). The main difference among the subsample is due to the more significance for women of variables $P O$ and assoc; this eventuality emphasizes perhaps the better women attitudes to associations.

\section{Discussion}

The empirical analysis has permitted to justify a gendered approach to farms' development. As a matter of fact, each hypothesis under study has revealed differences between men and women, being these differences linked to the various explanatory variables adopted in the model. The econometric model has been particularly effective in specifying which relevant variables affect most the probability of:

- getting higher economic performance,

- boosting strategies of diversification,

- networking and

- gaining access to rural policies.

As far as economic performance is concerned, our results seem coherent with both the feminist and the socialist view of female entrepreneurship: access to education affects business performance in female farms, so confirming the liberal feminist theory of gender difference, based on discriminatory factors in accessing key resources for farm development. Therefore, difficulty in accessing training and education seems character- 
Table 2 - Estimation results of the Logistic model.

\begin{tabular}{|c|c|c|c|c|c|c|c|c|c|c|}
\hline \multirow{2}{*}{\multicolumn{2}{|c|}{ Explanatory variables }} & \multicolumn{3}{|c|}{ Overall } & \multicolumn{3}{|c|}{ Women } & \multicolumn{3}{|c|}{ Man } \\
\hline & & \multirow{2}{*}{$\begin{array}{l}\text { Coef. } \\
0.542\end{array}$} & \multicolumn{2}{|l|}{$\begin{array}{l}\text { Robust } \\
\text { Std.Err }\end{array}$} & \multirow{2}{*}{$\begin{array}{c}\text { Coef. } \\
0.453\end{array}$} & \multicolumn{2}{|l|}{$\begin{array}{l}\text { Robust } \\
\text { Std.Err }\end{array}$} & \multirow{2}{*}{$\begin{array}{c}\text { Coef. } \\
0.980\end{array}$} & \multicolumn{2}{|l|}{$\begin{array}{l}\text { Robust } \\
\text { Std.Err }\end{array}$} \\
\hline \multirow{9}{*}{ ROI } & small & & $(0.255)$ & & & $(0.246)$ & & & $(0.343)$ & \\
\hline & fixasset & 1.255 & $(0.018)$ & $* * *$ & 1,125 & $(0.024)$ & $* * *$ & 1.586 & $(0.006)$ & $* * *$ \\
\hline & assoc & -0.076 & $(0.026)$ & $* * *$ & -0.199 & $(0.203)$ & & -0.137 & $(0.287)$ & \\
\hline & Area 1 & -1.353 & $(0.364)$ & & -1.521 & $(0.373)$ & & -1.636 & $(0.546)$ & \\
\hline & Area 2 & -0.093 & $(0.272)$ & & -0.695 & $(0.297)$ & & -0.639 & $(0.279)$ & \\
\hline & Area 3 & 0.123 & $(0.276)$ & & 0.535 & $(0.287)$ & & 1.097 & $(0.312)$ & \\
\hline & mediumlarge & -0.012 & $(0.282)$ & & -0.014 & $(0.398)$ & & -0.470 & $(0.334)$ & \\
\hline & $P O$ & 0.015 & $(0.012)$ & $* * *$ & 0.434 & $(0.003)$ & $* * *$ & 0.007 & $(0.051)$ & ** \\
\hline & education & 0.220 & $(0.035)$ & $* *$ & 0.398 & $(0.002)$ & *** & 0.029 & $(0.049)$ & $* *$ \\
\hline \multirow{5}{*}{ Diversification } & altitude & 0.105 & $(0.009)$ & $* * *$ & 0.281 & $(0.232)$ & & 0.243 & $(0.376)$ & \\
\hline & $P O$ & -0.007 & $(0.252)$ & & 0.318 & $(0.045)$ & $* * *$ & -0.212 & $(0.216)$ & \\
\hline & $\overline{a s s o c}$ & 0.028 & $(0.196)$ & & 0.261 & $(0.064)$ & $* *$ & -0.330 & $(0.232)$ & \\
\hline & farmhouse & -0.061 & $(0.003)$ & $* * *$ & -0.273 & $(0.150)$ & $*$ & -0.379 & $(0.047)$ & $* * *$ \\
\hline & organic & -0.002 & $(0.036)$ & $* *$ & 0.021 & $(0.047)$ & $* *$ & -0.262 & $(0.002)$ & $* * *$ \\
\hline \multirow{6}{*}{ Networking } & education & 0.921 & $(0.001)$ & $* * *$ & 0.945 & $(0.0002)$ & $* * *$ & 0.802 & $(0.0003)$ & $* * *$ \\
\hline & credit & 0.287 & $(0.006)$ & $* * *$ & 0.201 & $(0.174)$ & & -0.314 & $(0.004)$ & $* * *$ \\
\hline & service & 0.783 & $(0.009)$ & $* * *$ & -2.777 & $(0.062)$ & $*$ & -5.803 & $(0.004)$ & $* * *$ \\
\hline & Area 1 & -0.917 & $(0.052)$ & $* *$ & -1.216 & $(0.075)$ & $*$ & -6.457 & $(0.077)$ & $*$ \\
\hline & Area 2 & -0.213 & $(0.072)$ & $*$ & 0.654 & $(0.080)$ & $*$ & -0.601 & $(0.049)$ & $* *$ \\
\hline & Area 3 & 2.694 & $(0.067)$ & $*$ & 2.782 & $(0.073)$ & $*$ & 1.103 & $(0.082)$ & $*$ \\
\hline \multirow{15}{*}{ RDP fund } & Area 1 & 0.064 & $(0.007)$ & $* * *$ & 1.231 & $(0.046)$ & $* *$ & 0.260 & $(0.001)$ & $* * *$ \\
\hline & Area 2 & -2.319 & $(0.114)$ & & -1.456 & $(0.187)$ & & -2.328 & $(0.135)$ & \\
\hline & Area 3 & -0.334 & $(0.184)$ & & 0.713 & $(0.177)$ & & -2.251 & $(0.239)$ & \\
\hline & small & 2.325 & $(0.003)$ & $* * *$ & 2.276 & $(0.005)$ & $* * *$ & 5.194 & $(0.001)$ & $* * *$ \\
\hline & mediumlarge & -0.368 & $(0.209)$ & $*$ & -2.460 & $(0.566)$ & $* * *$ & -5.796 & $(0.754)$ & *** \\
\hline & education & 2.000 & $(0.046)$ & $* *$ & 1.866 & $(0.007)$ & $* * *$ & 3.319 & $(0.052)$ & *** \\
\hline & diversification & -1.178 & $(0.163)$ & & 0.734 & $(0.189)$ & & -1.432 & $(0.251)$ & \\
\hline & organic & -0.356 & $(0.294)$ & & -1.432 & $(0.317)$ & & -2.213 & $(0.243)$ & \\
\hline & offfarm & -0.020 & $(0.165)$ & & 0.298 & $(0.142)$ & & 0.024 & $(0.173)$ & \\
\hline & fixasset & 3.736 & $(0.007)$ & $* * *$ & 3.289 & $(0.004)$ & $* * *$ & 4.329 & $(0.003)$ & $* * *$ \\
\hline & fam_labor & -0.003 & $(0.001)$ & $* * *$ & -0.004 & $(0.003)$ & & -0.007 & $(0.003)$ & $* *$ \\
\hline & acc_serv & 0.931 & $(0.003)$ & $* * *$ & 4.248 & $(0.026)$ & $* *$ & 6.651 & $(0.001)$ & $* * *$ \\
\hline & assoc & -1.184 & $(0.045)$ & $* *$ & 0.893 & $(0.004)$ & $* * *$ & -0.794 & $(0.046)$ & $* *$ \\
\hline & $P O$ & 0.823 & $(0.038)$ & $* *$ & 1.319 & $(0.006)$ & *** & 0.219 & $(0.089)$ & $*$ \\
\hline & cons & -0.782 & $(0.006)$ & *** & -1.164 & $(0.037)$ & $* *$ & 0.106 & $(0.002)$ & *** \\
\hline \multicolumn{11}{|c|}{$\begin{array}{l}\text { Wald tests }(114)=160027.75, \mathrm{chi}^{2}=0.000 ; \text { Log likelihood }=-7658.244 ; \text { Pseudo- } \mathrm{R}^{2}=0.2628 \text {; } \\
\% \text { correctly predicted } 81 \%\end{array}$} \\
\hline
\end{tabular}

Statistical significance: $*=P<0.10 ; * *=P<0.05 ; * * *=P<0.01$; Robust standard errors in parenthesis; N.obs. $=6,234$. 
ising women farmers in both developed and developing countries (Roy et al., 2013). Moreover, the lack of socialization spaces emerges as key variable in conditioning economic female farms' performance, so validating socialist feminist theories. This element strongly emerges also for the networking hypothesis (H3) which points out a relatively lower level of relational assets hold by women. Consequently, a clear implication in normative terms emerge, in the light of a rural policies which even more relies on indirect tools for stimulating farm competitiveness, like producers' organization and other agricultural networks.

Despite the low capability of networking, news trajectories of female learning emerge, based on multifunctional agriculture, which create sound premises for building up new entrepreneurial female identities (Seuneke, Bock, 2015). These are often grounded on strategies of diversification aiming at raising the added value hold in the farm. The empirical analysis concerning diversification hypothesis (H2) confirms the propensity of women to uptake trajectories based on diversification in both agricultural and non-agricultural activities. These trends get along recent literature on willing reproduction strategies of female farms along path of sustainable agricultural development (Heather et al., 2005; Bock, 2004). As underlined in other recent studies (Unay-Gailhard, Bojnec, 2015 ; 2016; 2019), the transition from productivist to multifunctional paradigm of farming is sustained by funds from rural policies, tested in the H4 hypothesis. Differences in the access due to the propensity to adhere collective association emerge as explanatory variable fostering higher access to policy for women. This confirms recent studies in literature positing the heterogeneity of financial networks for supporting access to financial resources on behalf of women entrepreneurs (Leitch et al., 2018; Alakaleek, Cooper, 2018).

Therefore, from each hypothesis clear differences between men and women come to light, generating different policy implications.

\section{Conclusions}

Starting from a constituent perspective of women's role in agriculture (Whatmore, 1994), this paper tried to demonstrate gender differenc- es in performing agricultural activity, in terms of aggregate business results and in terms of diversification, networking and ability of getting funded from rural policies. On the other side, this perspective may be considered a limit of the analysis, above all in some family contexts where women's activity is carried out under the male's influence, within a neomarxist vision of family relationships (Shortall, 2002; Contzen, Forney, 2017). Therefore, in future researches, family composition and the stage of life cycle should be included in the empirical analysis to acquire a more detailed picture of decision-making process in the family farm business owned by women, then evidencing eventual phenomena of collective family farming and co-preneurship (Dyer et al., 2013; Dyer, 2018).

Nonetheless, our analysis may be considered a further step towards a more visible role of women in agricultural activity, as opposed to the subsidiary/invisible role underlined in last decades (Sachs, 1983; Little, Panelli, 2003). The profound differences between female and male worlds of production bring about a differentiated set of normative implication. However, a "policy gap" need to be underlined: concerns expressed by McElwee some years ago (McElwee, 2006, p. 70) may be considered only partially overcome: "current farm support policy may develop entrepreneurialism in men rather than women and thus there are gaps in policy, which need to be addressed". As previously posited about "masculine" criteria for accessing rural policies (Bock, 2004), there is a long road ahead, in account of the physical and structural criteria acting as real regulatory barriers to rural policies for women, to support their investment strategies. The removal of these barriers is the first, simple, step to grant a more democratic access to rural policies for women. On the policy provision side, a sort of "uneven approach" to gender mainstreaming emerges. As a matter of fact, rural development policies for the period 2007-2013 have specifically foreseen a privileged access to rural policies for women, while in the actual programming period, no reference to gender mainstreaming is indicated. Empirical analysis confirmed that specific variables affect women's performance: if, on the one side, edu- 
cation, networking and collective action emerge as engine of female farms' performance, targeted policies could strengthen these performances.

In account of distinctive trajectories of farm's development and innovation paths, as emerged from our analysis, refurbishing "women tailored interventions" seems appropriate, in order to consolidate alternative and sustainable trajectories of development in rural areas.

\section{References}

Alakaleek W., Cooper S.Y., 2018. The Female Entrepreneur's Financial Networks: Accessing Finance for the Emergence of Technology-based Firms in Jordan. Venture Capital, 20(2): 137-157.

Alsos G.A., Carter S., Ljunggren E., 2014. Kinship and business: how entrepreneurial households facilitate business growth. Entrepreneurship and Regional Development, 26(1-2): 97-122, DOI: 10.1080/08985626.2013.870235.

Anthopoulou T., 2010. Rural women in local agrofood production: Between entrepreneurial initiatives and family strategies. A case study in Greece. Journal of Rural Studies, 26(4): 394-403.

Banks J., Long A., van der Ploeg J.D., 2002. Living Countryside: Rural Development Processes in Europe - The State of the Art. Doetinchem: Elsevier.

Bensemann J., Hall C.M., 2010. Copreneurship in rural tourism: exploring woman's experiences. International Journal of Gender and Entrepreneurship, 2(3): 228-244.

Bird S.R., Sapp S.G., 2004. Understanding the gender gap in small business success: Urban and rural comparisons. Gender \& Society, 18(1): 5-28.

Blumberg R.L., 1988. Income under female versus male control: Hypotheses from a theory of gender stratification and data from the Third World. Journal of Family Issues, 9(1): 51-84.

Bock B.B., 2004. Fitting in and Multitasking: Dutch Farm Women's Strategies in Rural Entrepreneurship. Sociologia Ruralis, 44(3): 245-260.

Boden Jr R.J., 1999. Gender inequality in wage earnings and female self-employment selection. The Journal of Socio-Economics, 28(3): 351-364.

Brandth B., 2002. Gender identity in European family farming: A literature review. Sociologia Ruralis, 42(3): 181-200.

Brush C.G., Chaganti R., 1999. Businesses without Glamour? An Analysis of Resource on Performance by Size and Age in Small Service and Retail Firms. Journal of Business Venturing, 14(3): 233-257.
Calás M.B., Smircich L., 2006. From the 'Woman's Point of View' Ten Years Later: Towards a Feminist Organization Studies. In Clegg S., Hardy C., Nord W. (eds.), Handbook of Organization Studies. Thousand Oaks, CA: Sage Publications, pp. 218-258.

Carter N.M., Williams M., Reynolds P.D., 1997. Discontinuance among new firms in retail: The influence of initial resources, strategy, and gender. Journal of Business Venturing, 12(2): 125-145.

Carter S., Weeks J., 2002. Gender and Business Ownership - International Perspective on Theory and Practice. Entrepreneurship and Innovation, 3(2): 81-91.

Coleman S., 2002. Constraints faced by women small business owners: Evidence from the data. Journal of Developmental Entrepreneurship, 7(2):151-174.

Contzen S., Forney J., 2017. Family farming and gendered division of labour on the move: a typology of farming-family configuration. Agriculture and Human Values, 34: 27-40.

Council of Europe, 1998. Gender Mainstreaming, Conceptual framework, methodology and presentation of good practices. Final report of Activities of the Group of Specialists on Mainstreaming (EG-SMS), Strasbourg.

Cromie S., Birley S., 1992. Networking by female business owners in Northern Ireland. Journal of Business Venturing, 7(3): 237-251.

Damianos D., Giannakopoulos N., 2002. Farmers' participation in agri-environmental schemes in Greece. British Food Journal 104(3-4-5): 261-273.

Davidova S., Thomson K., 2014. Family farming in Europe. Challenges and prospects. Document prepared for the European Parliament's Committee on Agriculture and Rural Development, Brussels.

Defrancesco E., Gatto P., Runge F., Trestini S., 2008. Factors affecting farmers' participation in agri-environmental measures: A Northern Italian perspective. Journal of agricultural economics, 59(1): 114-131.

De Hoyos-Ruperto M., Romaguera J.M., Carlsson B., Lyytinen K., 2013. Networking: A Critical Success Factor for Entrepreneurship. American Journal of Management, 13(2): 56-72.

Delphy C., 1983. Agriculture et travail domestique: la réponse de la bergère à Engels. Nouvelles questions féministes, 5: 3-13.

Durkheim E., 1895. The rules of sociological method. New York: The Free Press.

Dyer W.G., 2018. Are Family Firms Really Better? Reexamining "Examining the 'Family Effect' on Firm Performance". Family Business Review, 3: 240-248. 
Dyer W.G., Dyer W., Gardner R., 2013. Should my spouse be my partner? Preliminary evidence from the panel study of income dynamics. Family Business Review, 26(1): 68-80.

Elfving J., Brännback M., Carsrud A.L., 2017. Revisiting a contextual model of entrepreneurial intentions. In: Brännback M., Carsrud A.L. (eds.), Revisiting the Entrepreneurial Mind: Inside the Black Box: An Expanded Edition. New York: Springer.

Errington A., Gasson R., 1993. The farm family business. Wallingford: Cab International.

Fairlie R.W., Robb A.M., 2009. Gender differences in business performance: evidence from the Characteristics of Business Owners survey. Small Business Economics, 33(4): 375-395.

Fasci M.A., Valdez J., 1998. A Performance Contrast of Male- and Female-Owned Small Accounting Practices. Journal of Small Business Management, 36(3): 1-7.

Fischer E.M., Reuber A.R., Dyke L.S., 1993. A theoretical overview and extension of research on sex, gender, and entrepreneurship. Journal of Business Venturing, 8(2): 51-168.

Griffin M., 2007. Specifying organizational contexts: Systematic links between contexts and processes in organizational behavior. Journal of Organizational Behavior, 28: 859-863.

Hafner-Burton E.M., Pollack M.A., 2009. Mainstreaming gender in the European Union: Getting the incentives right. Comparative European Politics, 7(1): 114-138.

Hanson S., Blake M., 2009. Gender and entrepreneurial networks. Regional Studies, 43(1): 135-149.

Heather B., Skillen L., Young J., Vladicka T., 2005. Women's gendered identities and the restructuring of rural Alberta. Sociologia Ruralis, 47(1-2): 86-97.

Hughes K.D., Jennings J.E., Brush C., Carter S., Welter F., 2012. Extending Women's Entrepreneurship Research in New Directions. Entrepreneurship theory and practice, 36(3): 429-442.

INEA, 2010. Banca dati RICA (FADN). Rome, Italy: Istituto Nazionale di Economia Agraria.

Johannisson B., Nilsson A., 1989. Community entrepreneurs: networking for local development. Entrepreneurship \& regional development, 1(1): 3-19.

Jones K., Tullous R., 2002. Behaviors of pre-venture entrepreneurs and perceptions of their financial needs. Journal of Small Business Management, 40(3): 233-249.

Kalleberg A.L., Leicht K.T., 1991. Gender and organizational performance: Determinants of small business survival and success. Academy of Management Journal, 34(1): 136-161.
Korsgaard S., Ferguson R., Gaddefors J., 2015. The best of both worlds: how rural entrepreneurs use placial embeddedness and strategic networks to create opportunities. Entrepreneurship and regional development, 27(9-10): 574-598.

Leitch C., Welter F., Henry C., 2018. Women entrepreneurs' financing revisited: taking stock and looking forward, Venture Capital, 20(2): 103-114.

Little J., 1987. Gender relations in rural areas: the importance of women's domestic role. Journal of rural studies, 3(4): 335-342.

Little J., 2006. Gender and Sexuality in Rural Communities. In: Cloke P., Marsden T., Mooney P. (eds.), The Handbook of Rural Studies. London: Sage Publication, pp. 365-378.

Little J., Jones O., 2000. Masculinity, gender, and rural policy. Rural Sociology, 65(4): 621-639.

Little J., Panelli R., 2003. Gender research in rural geography, Gender, place and culture, 10(3): 281-289.

Loscocco K.A., Robinson J., Hall R.H., Allen J.K., 1991. Gender and small business success: An inquiry into women's relative disadvantage. Social forces, 70(1): 65-85.

Lowe M., Lowe Bentson M., 1984. The uneasy alliance of feminism and academia. Women's Studies International Forum, 7: 177-183, DOI: 10.1016/0277-5395(84)90008-6.

Marlow S., McAdam M., 2013. Gender and Entrepreneurship: Advancing Debate and Challenging Myths; Exploring the Mystery of the Under-Performing Female Entrepreneur. International Journal of Entrepreneurial Behaviour \& Research, 19(1): 114-124, DOI: 10.1108/13552551311299288.

McElwee G., 2006. The enterprising farmer: a review of entrepreneurship in agriculture. Royal Agricultural Society of England Journal, 167: 66-75.

McElwee G., Bosworth G., 2010. Exploring the strategic skills of farmers across a typology of farm diversification approaches. Journal of farm management, 13(12): 819-838.

McGehee N.G., Kyungmi K., Gayle J.R., 2007. Gender and motivation for agri-tourism entrepreneurship. Tourism Management, 28(1): 280-289.

McKeever E., Anderson A., Jack S., 2014. Entrepreneurship and Mutuality: Social Capital in Processes and Practices. Entrepreneurship \& Regional Development, 26(5-6): 453-477, DOI: 10.1080/08985626.2014.939536.

Mirchandani K., 2002. Feminist insight on gendered work: new directions in research on women and entrepreneurship. Gender, Work and Organization, 6(4): 224-235. 
Moore D.P., 1999. An examination of present research on the female entrepreneur - suggested research strategies for the 1990s. Journal of Business Ethics, 9(4-5): 275-281.

Moore G., 1990. Structural determinants of men's and women's personal networks. American sociological review, 55(5): 726-735.

Naegels V., Neema M., D’Espallier B., 2018. An Institutional View on Access to Finance by Tanzanian Women-Owned Enterprises. Venture Capital, 20(2): 191-210.

Nau H., Steiner H., 2002. Schmoller, Durkeim, and old European institutionalist economics. Journal of Economics Issues, 1: 1005-1024.

Orhan M., 2001. Women business owners in France: The issue of financing discrimination. Journal of Small Business Management, 39(1): 95-102.

Oughton E., Wheelock J., Baines S., 2003. Micro-businesses and Social Inclusion in Rural Households: A Comparative Analysis. Sociologia Ruralis, 43(4): 331-348.

Popescu S., 2012. Women and Men in Entrepreneurship. Journal of Knowledge Management, Economics and Information Technology, 2(4): 1-9.

Prügl E., 2009. Does gender mainstreaming work? International feminist journal of politics, 11(2): 174-195.

Richter R., 1996. Bridging Old and New Institutional Economics: Gustav Schmoller, the Leader of the Younger German Historical School, Seen With Neoinstitutionalists' Eyes. Journal of Institutional and Theoretical Economics, 152(4): 567-592.

Rieux A., Dahache S., 2007. Women in Agriculture: The Invention of a Unique Agricultural and Domestic Management. Sociologies pratiques, 1: 45-57.

Robb A., Watson J., 2010. Comparing the performance of female-and male-controlled SMEs: evidence from the United States and Australia. Frontiers of Entrepreneurship Research, 30(8).

Rosa P., Hamilton D., Carter S., 1994. The Impact of Gender on Small Business Management: Preliminary Findings of a British Study. International Small Business Journal, 12(3): 25-32, DOI: 10.1177/0266242694123002.

Roy D., Farouque M.G., Rahman M.Z., 2013. Problem confrontation of the FFS farmers in participating farmer field school training session. Progressive Agriculture, 24(1-2): 273-280.

Sachs C., 1983. Invisible Farmers: women's work in agricultural production. Totowa, NJ: Rhinehart Allenheld.

Scott A., 1986. Industrialization, gender segregation and stratification theory. In: Crompton R., Mann M. (eds.), Gender and stratification. Cambridge: Polity Press, pp. 154-189.

Seuneke P., Bock B.B., 2015. Exploring the roles of women in the development of multifunctional entrepreneurship on family farms: an entrepreneurial learning approach. NJAS Wageningen Journal of Life Science, 74-75: 41-50.

Shortall S., 2002. Gender and rural restructuring: a case study of Northern Ireland. Sociologia Ruralis, 42(2): 160-176.

Shortall S., 2006. Gender and farming: An overview. In: Bock B.B., Shortall S. (eds.), Rural gender relations: Issues and case studies. Wallingford: CABI Publishing, pp. 19-26.

Stratigaki M., 2005. Gender mainstreaming vs positive action: An ongoing conflict in EU gender equality policy. European Journal of Women's Studies, 12(2): 165-186.

Swinney J.L., Runyan R.C., Huddleston P., 2006. Differences in reported firm performance by gender: Does industry matter? Journal of Developmental Entrepreneurship, 11(2): 99-115.

Tigges L.M., Green G.P., 1994. Small business success among men-and women-owned firms in rural areas. Rural Sociology, 59(2): 289-310.

Torre A., Traversac J.B., 2011. Territorial Governance. Local Development, Rural Areas and Agrofood Systems. Heidelberg-New York: Springer.

Trauger A., 2004. Because they can do the work': Women farmers in sustainable agriculture in Pennsylvania, USA. Gender, Place \& Culture, 11(2): 289-307.

Unay-Gailhard İ., Bojnec Š., 2015. Farm size and participation in agri-environmental measures: Farm-level evidence from Slovenia. Land Use Policy, 46: 273-282.

Unay-Gailhard İ., Bojnec Š., 2016. Sustainable participation behaviour in agri-environmental measures. Journal of Cleaner Production, 138: 47-58.

Unay-Gailhard İ., Bojnec Š., 2019. The impact of green economy measures on rural employment: green jobs in farms. Journal of Cleaner Production, 208: 541-551.

Van der Ploeg J.D., Marsden T., 2008. Unfolding webs. Assen: Van Gorucm.

Vanslembrouck I., van Huylenbroeck G., Verbeke W., 2002. Determinants of the Willingness of Belgian Farmers to Participate in Agri-environmental Measures. Journal of agricultural economics, 53(3): 489-511.

Vik J., McElwee G., 2011. Diversification and the entrepreneurial motivations of farmers in Norway. Journal of Small Business Management, 49: 390-410. 
Watson J., Newby R., 2005. Biological sex, stereotypical sex-roles, and SME owner characteristics. International Journal of Entrepreneurial Behaviour and Research, 11(2): 129-143.

Welter F., 2011. Contextualizing entrepreneurship. Conceptual challenges and ways forward. Entrepreneurship: Theory and Practice, 35(1):165184.

Welter F., Brush C., de Bruin A., 2014. The gendering of entrepreneurship context. In: Proceedings of the RENT XXVII, Vilnius, Lithuania, 21-23, 2013.

Welter F., Gartner W.B. (eds.), 2016. A research agen- da for entrepreneurship and context. Cheltenham UK: Edward Elgar Publishing.

Welter F., Gartner W.B., Wright M., 2016. The context of contextualizing contexts. In: Welter F., Gartner W.B. (eds.), A research agenda for entrepreneurship and context. Cheltenham UK: Edward Elgar Publishing.

Whatmore S., 1994. Theoretical achievements and challenges in European rural gender studies. Rural society, 4: 39-49.

Whatmore S., 2016. Farming women: Gender, work and family enterprise. New York: Springer. 